\title{
CORRECTION
}

\section{Correction to: Safety Risk Analysis and Accidents Modeling of a Major Gasoline Release in Petrochemical Plant}

\author{
Abderraouf Bouafia (D) Mohammed Bougofa - Mounira Rouainia • \\ Mohamed Salah Medjram
}

Published online: 14 February 2020

(C) ASM International 2020

Correction to: J Fail. Anal. and Preven.

https://doi.org/10.1007/s11668-020-

00826-9

In the original version of the article, Mounira Rouainia's last name was spelled wrong. It is correct as shown here. The original article has been updated.
Publisher's Note Springer Nature remains neutral with regard to jurisdictional claims in published maps and institutional affiliations.

The original article can be found online at https://doi.org/10.1007/ s11668-020-00826-9.

A. Bouafia $(\bowtie) \cdot$ M. Rouainia $\cdot$ M. S. Medjram

Laboratoire de Génie Chimique et Environnement de Skikda,

Université de 20 août 1955, Skikda, Algeria

e-mail: a.bouafia@univ-skikda.dz

M. Bougofa

Laboratoire ingénierie des transports et environnement,

Université des Frères Mentouri - Constantine 1, Constantine,

Algeria 